\title{
The Spiritual Dimension of Family Life
}

Julia Pryce

Loyola University Chicago, jpryce@luc.edu

Froma Walsh

Follow this and additional works at: https://ecommons.luc.edu/socialwork_facpubs

Part of the Social Work Commons

\section{Recommended Citation}

Pryce, Julia and Walsh, Froma. The Spiritual Dimension of Family Life. Normal Family Processes, 3rd edition, , : 337-375, 2003. Retrieved from Loyola eCommons, Social Work: School of Social Work Faculty Publications and Other Works, http://dx.doi.org/978-1572308169

This Book Chapter is brought to you for free and open access by the Faculty Publications and Other Works by Department at Loyola eCommons. It has been accepted for inclusion in Social Work: School of Social Work Faculty Publications and Other Works by an authorized administrator of Loyola eCommons. For more information, please contactecommons@luc.edu. (c) $($ ) $(9)$

This work is licensed under a Creative Commons Attribution-Noncommercial-No Derivative Works 3.0 License. (c) Guilford Press, 2003. 


\title{
THE SPIRITUAL DIMENSION OF FAMILY LIFE
}

\author{
Froma Walsh \\ Julia Pryce
}

ver the centuries and across cultures, spiritual beliefs and practices have anchored and nourished families and their communities. Families have lit candles, prayed together, meditated, and quictly turned to faith for solace, strength, and connectedness in their lives. At times of crisis and adversity, spiritual beliefs and practices have fostered recovery from trauma, loss, and suffering. Today, the vast majority of families adopt some form of expression for their spirituality. Yet mental health professionals and social scientists have tended to neglect this vital dimension in their understanding of family functioning and in the treatment of distress. This chapter briefly examines the growing importance and diversity of religion and spirituality for families and considers their influence in family coping and resilience.

Spirituality is not simply a special topic, although some families may have particular spiritual concerns. Rather, like culture and ethnicity, it involves streams of experience that flow through all aspects of life, from family heritage to personal belief systems, rituals and practices, and shared faith communities. Spiritual beliefs influence ways of dealing with adversity, the experience of pain and suffering, and the meaning of symptoms. They also influence how people communicate about their pain; their beliefs about its causes and future course, their attitudes toward helpersclergy, physicians, therapists, faith healers, the tratments they scek, and

Revised from Chapters 1 and 2 in Froma Walsh (Ed.). (1999). Spiritual resources in famil) therapj. New York: Guilford Press. 
their preferred pathways to recovery. Many who seek help for physical, emotional, or interpersonal problems are also in spiritual distress. It is therefore important for clinicians and researchers to attend to the spiritual practices and beliefs of families as a source of understanding, as well as a potential contribution to family healing and growth.

\section{RELIGION AND SPIRITUALITY IN A CHANGING WORLD}

At the dawn of the 21 st century there has been a resurging interest in religion and spirituality as people have sought greater meaning, harmony, and connection in their lives. Over recent decades, families worldwide have experienced tumultuous social and economic dislocations, generating widespread spiritual malaise (Lerner, 1994). As the world changes at an accelerated pace, daily lives may seem on the brink of chaos. Harried, fragmented schedules undermine a sense of identity, well-being, and purpose (Hochschild, 1997). Poverty and lack of hope for future possibilities can generate despair-literally, loss of spirit (Aponte, 1994). Among the affluent, the accumulation of material goods fails to provide fulfillment. The saturation of media images of sex and violence leaves a hunger for substance and moral integrity. Besieged parents are unsure how to raise their children well in a hazardous world, and how to counter destructive pressures of popular culture (Pipher, 1997). The ethos of the "rugged individual" and decades of self-orientation contribute to the breakdown of communities and the fraying of our social fabric, accompanied by a widespread sense of isolation, powerlessness, and despair (Bellah, Madsen, Sullivan, Swidler, \& Tipton, 1985). Many feel adrift on their own fragile life rafts in a turbulent sea (Lifton, 1993).

Amid such changes, marriage and family life have become more challenging over recent decades. With the growing diversity of family forms and cultural values, changing gender roles, and varied life-cycle course, no single model fits all. Instead, families need to reinvent themselves, many times over, to fit the demands of our times (Walsh, 1998a; see Chapter 1, this volume). Disruption and confusion accompany changes in the structure of family relationships as members redefine their values, practices, and living arrangements.

As baby boomers age and grapple with their own mortality and the death of loved ones, there is a growing impetus to explore the meaning of life and the mystery of a spiritual afterlife. The AIDS epidemic heightened consciousness of life and death issues. The rise of terrorism has shattered American illusions of invulnerability. With the attacks of $9 / 11$ many were jolted into awareness of the precariousness of life and the interconnections of all people on our planet. In the aftermath, people turned, above all else, to their loved ones and to their faith for meaning, support, and strength in facing an uncertain future. 
It may be an illusion that life was ever more secure in earlier times as seen through the rose-colored lens of nostalgia (Walsh \& McGoldrick, 1991). Yet many are alarmed by a seeming collapse of universal moral values in the relativism of our postmodern era (Browning, Miller-McLemore, Couture, Lyon, \& Franklin, 2001). The rise in religious fundamentalism in many parts of the world can be seen as one expression of a need to return to traditions that provide clear structure, pure values, and absolute certainties in the face of rapid social change. Buffeted by societal and global forces seemingly beyond control or comprehension, many feel a yearning for inner peace, for a sense of wholeness and coherence in fragmented lives, and for more meaningful connection with others beyond the self.

\section{DEFINING RELIGION AND SPIRITUALITY}

As we consider the concepts of religion and spirituality in contemporary families, it is important to clarify our understanding of these terms, which are often used interchangeably. Wright, Watson, and Bell (1996) offer some useful distinctions between religion, as extrinsic, organized systems, and spirituality, as more intrinsic personal beliefs and practices.

\section{Religion: Organized Belief System and Affiliation}

"Religion" can be defined as an organized belief system that includes shared, and usually institutionalized, moral values, beliefs about God or a Higher Power, and involvement in a faith community. Religions provide standards and prescriptions for individual virtue and family life grounded in core beliefs. Particular ideas and practices are often unquestioned, accepted as right or true. Congregational affiliation provides social and health benefits, as well as support in times of crisis.

Rituals and ceremonies offer participants a sense of collective self. In all religions, the family is central in rites that mark the birth of a new member, entry into the adult community, marriage vows, and the death of a loved one. For instance, the practice of Judaism is centered on the family observance of rituals, from weekly Shabbat candle lighting to the major holidays in the Jewish calendar year and rites of passage across the life cycle. Each ritual is significant, connecting family members with their larger community and its history, their covenant with God, and their survival over adversity.

\section{Spirituality: Transcendent Beliefs and Practices}

Spirituality, an overarching construct, refers more generally to transcendent beliefs and practices. Spirituality can be experienced either within or outside formal religious structures and is both broader and more person- 
al. A simple, yet profound definition of spirituality is "that which connects one to all there is" (Griffith \& Griffith, 2001). Spirituality involves an active investment in an internal set of values and fosters a sense of meaning, wholeness, harmony, and connection with others (Stander, Piercy, Mackinnon, \& Helmeke, 1994). One's spirituality may involve belief in a supreme being, a striving toward an ultimate human condition, or a unity with all life, nature, and the universe (Wright et al., 1996). Spiritual resources might range from secular humanistic principles to congregational affiliations to personal practices of meditation or traditional faith-healing rituals. It may include numinous experiences that are holy or mystical. Spiritual and religious belief systems provide faith explanations of past history and present experiences; for many, they predict the future and offer pathways toward understanding the ultimate meanings of life and existence (Campbell \& Moyers, 1988).

Spirituality invites an expansion of consciousness, along with personal responsibility for and beyond oneself, from local to global concerns. A child's growing moral awareness evolves out of spiritual belief systems (Coles, 1990, 1997). Morality involves the activity of informed conscience: judging right and wrong based on principles of fairness, decency, and compassion (Doherty, 1995, 1999). Moral or ethical values spur actions beyond repair to improve conditions, to respond to the suffering of others, to dedicate efforts to help others, and to alleviate injustice (Perry \& Rolland, 1999). At their best, ethical values promote humanity.

Universally, the spirit is seen as our vital essence, the source of life and power. In many languages the word for "spirit" and "breath" are the same: in Greek, pneuma; in Hebrew, reach; in Latin, spiritus (Weil, 1994). Similarly, the soul has been seen over the ages as the source of human genuineness, depth, joy, sorrow, and mystery. Herbert Anderson (1994; 1999), a leading theological educator on marriage and the family, defines the "soul" as something like the visualizing center of life, the quality of living with ourselves and others. We can only glimpse it in part and cannot penetrate its essence. Taking a double view, Anderson describes soul as everywhere but nowhere, in every cell of the body and also capable of selftranscendence. Thus, we are both soul-filled bodies and embodied souls. As Thomas Moore (1992) affirms, "It takes a broad vision to know that a piece of sky and a chunk of the earth lie lodged in the heart of every human being, and if we are to care for that heart we will have to know the sky and earth as well as human behavior" (p. 20). Such perspectives are strikingly akin to Native American spirituality (Deloria, 1994).

Some regard the "loss of soul" as a primary source of the maladies of our times, afflicting individuals and society. Moore (1992) asserts: "When soul is neglected ... it appears symptomatically in obsessions, addictions, violence, and loss of meaning" (p. xi). The temptation is to isolate these symptoms or try to eradicate them one by one; but the root problem is the 
loss of wisdom about the soul, resulting in a deficit of human spirit. Someone in despair is referred to as a "lost soul," lacking purpose or community, struggling to survive. Much of the suffering that is given pathological labels in therapeutic settings may also be understood as maladies of the soul, yearnings for meaning and connection.

Tending to the soul involves purposeful activity and restful replenishing. When lost in a multitude of activities and petty concerns, the soul is endangered. Soul also involves vulnerability and uncertainty; as humans, all are susceptible to being wounded. The soul is nourished by living without pretense or armor, approaching all experience with openness, courage, and compassion.

\section{SPIRITUAL BELIEFS AND PRACTICES: GROWING IMPORTANGE AND DIVERSITY}

The United States is one of the most religious nations in the industrialized world in the level of attested spiritual beliefs and practices. Since 1939, Gallup surveys have been polling Americans about their spiritual/religious beliefs and affiliations. ${ }^{1}$ Religious interest and church attendance surged after World War II, through the 1950s, with televised evangelists reaching into family homes. Religious involvement declined somewhat from the late 1960s through the 1980s, but found renewed vitality in the 1990s, in an expanding landscape of faiths. Today, $85 \%$ of all adults say religion is important in their lives; nearly $60 \%$ consider it very important, and one-third view it as the most important part of their lives (Princeton Religion Research Center; Gallup, 1996; Gallup \& Lindsey, 1999).

\section{Intertwining of Spirituality and Family Functioning}

Spirituality and family life are deeply intertwined (Burton, 1992; D'Antonio, Newman, \& Wright, 1982). Family process research has found that transcendent spiritual beliefs and practices are key ingredients in healthy family functioning (Beavers \& Hampson, 1990, Chapter 20, this volume; Stinnett \& DeFrain, 1985). A system of values and shared beliefs that transcend the limits of their experience and knowledge enables family members to better accept the inevitable risks and losses in living and loving fully. Gallup surveys (Gallup \& Lindsey, 1999) consistently support these findings: Nearly $75 \%$ report that their family relationships have been strengthened by religion in the home. Over $80 \%$ say that religion was important in their family of origin, when they were growing up. Notably, these people were also significantly more likely to report that religion greatly strengthens current family relationships. 


\section{Family Values}

Family values have become a hotly debated topic in political discourse. Some conservatives have asserted that the changing family forms and gender roles over recent decades have led to the demise of the family and the decay of "family values." In an era of growing family diversity and a rich variety of kinship patterns, it is crucial to move beyond the myth that one model of the family is the paragon of virtue for all to emulate and that others are inherently damaging (Stacey, 1996; see Walsh, Chapter 1, this volume). Family form has been confused with family substance: Family processes and community connections that strengthen the quality of relationships are most crucial for families and their members to thrive (Walsh, 1998a).

All families have values-even those who have difficulty in their consistent practice. Some contemporary family values break with cultural and religious traditions, as in the conviction that men and women should be equal partners in marriage and family life (see Haddock, Zimmerman, \& Lyness, Ch. 12, this volume). Yet most families uphold values that maintain continuity with the past in terms of commitment, personal responsibility, and the strong desire to raise children to be healthy and have a good life (Doherty, 1999). In recent surveys (Gallup, 1996), "family ties, loyalty, and traditions" were ranked as the main factors thought to strengthen the family. Next, were "moral and spiritual values based on the Bible," which far outranked "family counseling," "parent training classes," and "government laws and policies."

\section{Spirituality across the Family Life Cycle}

Spirituality involves dynamic processes that ebb and flow, and change in meaning over the life course and across the generations (Worthington, 1989). In the family life cycle, marriage often brings religious considerations to the fore. Conflict may arise over the wedding itself, such as whether to have a religious or civil ceremony. Even partners of the same faith may differ in their particular sect or degree of observance and preferences for clergy and marital vows. Families of origin may exert pressures for wedding plans in line with their own convictions, often fueling intergenerational conflict and in-law triangles that can reverberate over the years. The desire for a religious commitment ceremony by gay and lesbian couples may be met with family or congregational disapproval (see Laird, Chapter 7 , this volume).

Interfaith marriage can complicate the issues couples ordinarily bring to any relationship (Falicov, 1995; see McGoldrick, Chapter 9, this volume). Under stress, tolerance for differences can erode, particularly if one way is believed to be right and morally superior, with the other viewed as wrong or even immoral. It can matter a great deal whether both families of 
origin approve of the marriage and attend the wedding. In some cases, the choice of a spouse from a different religious background may express rebellion against parental values and authority (Friedman, 1985). Family acceptance or disapproval can have long-lasting ramifications for the success or failure of the marriage and for intergenerational relations.

Remarriage can also pose unexpected dilemmas. For orthodox Jews, a woman wishing to remarry after divorce must obtain a "get," or written permission from her ex-spouse, although a man wanting to remarry is not expected to do so (Rosen \& Weltman, 1996). The Catholic Church allows divorce but only sanctions remarriage in cases of annulment. This strict ruling has led many Catholics to leave the church at remarriage. Other couples may decide to live together without legal remarriage or religious rites. Desire to remarry has also led a growing number of Catholics to petition the church for annulment of a former marriage. Such annulments are commonly granted, especially to influential men, even after a long marriage and over objections of a wife and children, who may be deeply wounded that an annulment invalidates their prior family life and legitimacy. It is crucial to explore such potentially painful and conflict-laden religious issues in working clinically with separated, divorced, and remarried families, and with co-habiting couples.

The vast majority of parents want their children to have religious training (Gallup \& Lindsey, 1999). In interfaith marriages, differences that initially attracted partners may over time become contentious in raising children. Couples who may have viewed religion as unimportant in their lives may later find that one or both partners care deeply about the religious upbringing of their children. Conflicts may arise over decisions about rituals such as christening, baptism, or bar/bat mitzvah. Here again, the older generation, now as grandparents, may make their religious preferences strongly known. Previous acceptance of their children's choice of a nontraditional wedding or an interfaith marriage may shift when they consider the moral development and religious identification of their grandchildren. This is an especially agonizing issue in the Jewish community, with high rates of interfaith marriage in recent decades. Studies suggest that if the gentile partner converts to Judaism, children are more likely to grow up with a Jewish identity and practice the faith.

Most teenagers say it is important for parents and younger children to attend services together (Gallup, 1996). Sometimes it is the children who draw parents back to religious roots. It may surprise some that $95 \%$ of teenagers report that they believe in God, and nearly $50 \%$ claim they went to church or synagogue in the past week. Three in four say they pray when alone. Over $60 \%$ report a great deal of interest in discussing the existence of God; over $50 \%$ express interest in discussing life's meaning and how to make moral decisions (Gallup, 1996). Like their parents, over $80 \%$ of teenagers follow Judeo-Christian faiths. Only $9 \%$ state no religious preference. 
Young adults, particularly those in college, often distance from their religious upbringing (Elkind, 1971). Of note, 15\% of college freshmen report no religious preference (Gallup, 1996). Some young adults simply become less involved and lose faith, whereas others more actively question their religion or cut off altogether from their family's traditions. Many explore other religions or nontraditional ways of experiencing spirituality. A family member who chooses to convert or "marry out" may be seeking to rebalance the family's ethnic or religious orientation, moving away from some values and toward others. In some cases, this may express an attempt to separate and differentiate from one's family of origin (Friedman, 1985). Parents may experience such a choice as a rejection of them. Indeed, some young adults may wish to cut off from religious or parental upbringing that was experienced as oppressive. More often, though, it is simply a natural attraction between two individuals of diverse backgrounds in an increasingly multicultural society.

Middle to later life is a time of growing saliency of spiritual values as family members grapple with questions about the meaning of life, deal with the deaths of parents and other loved ones, and begin to face their own mortality (Erikson, Erikson, \& Kivnick, 1986). Over half of all adults expect religion to become increasingly important to them as they age. Surveys find that active congregational participation and prayer tend to increase over adulthood. Whereas only $35 \%$ of young adults aged 18-29 attend their place of worship weekly, $41 \%$ of persons aged $30-49,46 \%$ of those aged 50-64, and 56\% of those over 65 attend weekly. The wisdom of elders is surely deepened by their growing spirituality (Walsh, 1998c).

\section{Growing Religious Pluralism}

The principle of respect and tolerance for religious differences was a core value in the founding of the United States (Gaustad, 1966). Although predominantly Christian through the mid- 20th century (Greeley, 1969), the population has grown increasingly diverse in spiritual beliefs and practices in recent decades. The religious landscape has changed dramatically as people seek spiritual expression and connection in varied ways.

Over $90 \%$ of Americans identify with a specific religion. The country remains primarily Christian (84\%), and largely Protestant (58\%), although membership has been shifting from mainline to Baptist and other evangelical denominations (Gallup \& Lindsey, 1999). Twenty-six percent of Americans are Roman Catholic. Additionally, $1 \%$ are Mormon (Church of the Latter-Day Saints), and 1\% are Eastern Orthodox (such as Greek or Russian).

Many denominations are hard to distinguish; terms such as "fundamentalist," "evangelical," and "charismatic" are blurred, overlapping, and in flux. Nearly $20 \%$ of adults think of themselves as belonging to the religious Right (Gallup, 1996), with the highest identification for women, 
Southerners, blacks, seniors, and those who did not attend college. This is actually a heterogeneous group. For some, the "Christian Right" is a broad-based interracial, interfaith coalition combining fundamentalist visions of religion with politically and socially conservative agendas. Yet among those who consider themselves "born again" or evangelical Christians $(18 \%)$, only one-third hold conservative social and political ideologies and identify with the religious Right. Therefore, it is important to clarify each family's beliefs without making assumptions.

The non-Christian proportion of the U.S. population has been rising rapidly: from $3.6 \%$ in 1900 , to $9.9 \%$ in 1970 , to $14.6 \%$ by 1995 (Gallup, 1996). Two percent of Americans identify as Jewish (down from $5 \%$ in the1950s but stable since 1972). Five percent follow other religionsIslam, Hinduism, and Buddhism, each currently at $1 \%$, are growing rapidly. (Worldwide, Muslims will soon outnumber Christians.) Still others identify with such faiths as Sikh, Bahaii, Shintoism, and Taoism. A strong revival of Native American spiritual heritage has occurred. Some are drawn to mysticism from varying religious traditions. The New Age movement blends a range of approaches for people whose spiritual needs have not been met by conventional religions.

Some are drawn to religious cults, cutting off from their families and communities to live communally and follow the ideology of a charismatic leader, who may be seen as a prophet (Galanter, 1989). Anguished families may seek help to recover and "deprogram" a family member lost to such groups. The turn of the millennium saw an upsurge in apocalyptic prophesies of the end of the world, "doomsday cults," and survivalist communes. Religious extremist groups, although small in number, have posed a growing threat of violence. Although Muslim fundamentalist terrorists view themselves as adherents of Islam, the Koran does not condone the killing of innocent people or suicide, and the vast majority of Muslims abhor such acts. In the United States, violence has also been sparked by members of right-wing white militia movements, many associated with extremist Christian groups that espouse creeds of racism and religious intolerance. Imposition of the dogmatic belief that there is only one "true religion" has led to catastrophic consequences throughout human times, as in holy wars to convert, subjugate, or annihilate nonbelievers.

\section{Religious Congregations}

With organized religion flourishing in many forms, there are currently over 2,000 denominations plus countless independent churches and faith communities (Gallup, 1996; Lindner, 1998). There are nearly 500,000 churches, temples, and other places of worship, from small storefront congregations to huge amphitheaters drawing thousands of worshipers. Membership in a church, synagogue, or other religious body has been consistently high—nearly 7 in 10 persons-over the past 50 years. Nearly 6 in 10 
persons report that they attend services monthly; 4 in 10 attend weekly (including $50 \%$ of all women compared to $37 \%$ of men).

Most religious congregations encourage active participation through choir and prayer groups, suppers and social gatherings, as well as service and charity work. Religious support groups help members find strength in helping one another. Congregants view the clergy as dealing well with the needs of their parishioners and the problems of their communities. Religious leaders are generally held in high esteem: Clergy are ranked second to pharmacists as the profession most respected in terms of honesty and ethical standards-slightly ahead of doctors, dentists, engineers, and college professors (Gallup, 1996). (Ranked lowest are members of Congress and car salesmen!)

\section{Religion and Multicultural Influences}

Religion and culture are interwoven in all aspects of spiritual experience. Frank McCourt (1998) describes the image of God he formed in his Irish Catholic upbringing:

We didn't hear much about a loving God. We were told God is good and that was supposed to be enough. Otherwise the Irish Catholic God of my memory is one the tribes of Israel would have recognized, an angry God, a vengeful God, a God who'd let you have it upside your head if you strayed, transgressed, coveted. ... He had His priests preaching hellfire and damnation from the pulpit and scaring us to death. We were told that the Roman Catholic Church was the One True Church, that outside the Church there was no salvation. (p. 64)

McCourt developed two different versions of God in his head-Irish and Italian:

Our faith was mean, scrimped, life-denying. We were told this was a vale of tears, transitory, that we'd get our reward in heaven, if, that is, we'd stop asking those dumb questions. ... Statues and pictures of the Virgin Mary in the Irish churches seemed disembodied and she seemed to be saying, "Who is this kid?" In contrast Italian art portrayed a voluptuous, maternal Mary with a happy infant Jesus at her bosom. (p. 64)

McCourt wondered: "Was it the weather? Did God change His aspect as He moved from the chilly north to the vineyards of Italy?" (p. 64). He thought that, all in all, he'd prefer the Italian expression of Catholicism to the Irish one.

Religious adherence and more personal spiritual beliefs and practices vary greatly across and within cultures. For instance, U.S. Muslims include African Americans and immigrants from South Asia, the Middle East, north and sub-Saharan Africa, Pakistan, and Indonesia. All Muslims perform the same daily prayers and share a common set of precepts from the 
Holy Koran that guide daily life. Yet each family places a distinct cultural stamp on its practices (Mahmoud, 1996). Within cultures, differences are also found between families from rural, traditional backgrounds and those from urban settings, with more education and middle-class values. Religion is further intertwined with influences such as race, recent immigration, and the degree of fit vis-à-vis the dominant culture or local community. Religious prejudice or outright discrimination leads some to suppress their religious identification or expression.

Ethnicity influences religious preference, yet it is crucial not to reflexively link religion with ethnicity. Although Hispanics are commonly assumed to be Catholic, in fact, just $60 \%$ are Catholic, whereas $25 \%$ are Protestant. Contrary to popular belief, only one-third of Arab Americans are Muslim; many are Christian. Although most Irish are Catholic, those from Northern Ireland may well be Protestant. Streams of recent immigrants from Southeast Asia may be Christian or bring Eastern religious traditions. Some come, as immigrants did historically, fleeing religious persecution in their country of origin, such as Russian Jews. Refugees from the former Yugoslavia are not only Serbian, Croatian, or Bosnian, but also Orthodox Christian, Catholic, or Muslim-differences that carry heavy historical meaning (i.e., the imposition of Islam by invading Turks) and have fueled hatred and bloodshed across generations.

Among African Americans, 73\% are Protestant, $10 \%$ are Catholic, and a growing number are Muslim (Gallup, 1996). Blacks of all faiths are far more likely than others to consider religion important: Religious experience starts young and continues throughout their lives. Most African Americans participate actively in their local church congregation. They take religion seriously, practice it fervently, and look to it for strength in dealing with adversity (Billingsley, 1992; Boyd-Franklin \& Lockwood, 1999; see Chapter 10, this volume).

The wide spectrum of faiths today has been called a "supermarket" of religions. However, in a predominantly Christian nation of European origins, we must be cautious not to superimpose the template of western European values on other belief systems and practices that may not be understood in Christian terms. It is crucial not to judge diverse faith traditions, particularly those of tribal peoples, as inferior when they differ from EuroChristian standards, such as African healing traditions (Some, 1994). Early Euro-American conquerors viewed Native Americans as primitive heathens and regarded their spiritual beliefs and practices as pagan witchcraft. Such attitudes led the government and religious missionary programs to educate and acculturate Indians in Christianity and Western ways, eradicating their own tribal language, religion, and customs. Children, taken from their families and isolated in boarding schools, were stripped of their cultural identity and religious heritage. Today, native youth are returning in large numbers to the spiritual roots of their ancestors, seeking identity and worth in their spiritual community (Deloria, 1994). 


\section{Common Spiritual Beliefs and Practices}

It may surprise many secular therapists and social scientists that $96 \%$ of Americans believe in God or a universal spirit, although these conceptions vary widely. Only 3\% are atheists, not believing in the existence of God, and $1 \%$ are agnostic, uncertain about whether God exists (Gallup, 1996; God in America, 1998). Some think of God as a "force" that maintains a balance in nature, but most people believe in a personal God who watches over and judges people. Eight persons in 10 feel that God has helped them to make decisions. Most believe that God performs miracles today. Many say they have felt the presence of God at various points in their lifetime and believe that God has a plan for their lives. The closer people feel to God, the better they feel about themselves and others. Most people believe that they will be called before God on Judgment Day to answer for their sins (Gallup, 1996). Eighty percent of Americans believe in an afterlife; $72 \%$ believe in heaven, and most believe in angels. Fifty-six percent believe in Hell, and $50 \%$ believe in the devil. Seventy-five percent rate their own chances of going to heaven as excellent or good (even though a few are not sure of its existence)!

The vast majority of Americans are Christian or Jewish, who believe the Bible was either the literal or inspired word of God and regard the Ten Commandments as valid rules for living. For Muslims, the Koran builds on those foundations and provides specific guidelines and prohibitions for individual, family, and community life (Almeida, 1996). Every religion has a precept akin to "Treat others as you would want them to treat you."

Religious beliefs profoundly influence character development. Eight people in 10 say that their religious convictions help them to respect themselves and other people, and to assist those in need. Six in 10 report that religion answers their questions and helps them to solve their problems. Furthermore, most say their beliefs keep them from doing things they know they should not do. One-third report a profound spiritual experience, either sudden or gradual, that dramatically altered their lives. Those who say religion is the most important influence in their lives, and those who receive a great deal of comfort from their faith, are far more likely to feel close to their families, to find their jobs fulfilling, and to be hopeful about the future (Chamberlain \& Zika, 1992).

\section{Prayer and Meditation}

Prayer has strong meaning for Americans: 90\% say they pray in some fashion at least weekly; $75 \%$ pray daily (Gallup, 1996). For most, prayer originates in the family and is centered in the home. Prayer at bedtime and saying Grace or giving thanks to God before meals are common practices. Most people report that they pray whenever they feel the need. Almost all $(98 \%)$ pray for their family's health and happiness. Few $(5 \%)$ pray for bad 
tidings for others. Prayer generates feelings of hope and peace. Most who pray $(86 \%)$ believe it makes them better persons. Nearly all report that their prayers have been heard and answered. Most $(62 \%)$ say they got what they hoped for, and most $(62 \%)$ have received divine inspiration or a feeling of being led by God. Twenty-five percent report a voice or vision as a result of prayer. Some $(30 \%)$ have stopped praying for long periods of time, mostly because they got out of the habit. Few $(10 \%)$ stopped because they had lost their faith, were angry with God or the church, or felt their prayers had not been answered.

Every religion values some form of prayer or meditation. It may involve chanting, reading scriptures, or rituals such as lighting candles or incense, reciting a rosary, or, for Muslims, observing the call to prayer five times daily. Most pray to a Supreme Being, such as God, Allah, Jehovah, or to Jesus Christ. Very few report that they pray to a transcendent or cosmic force, or to "the god within." One reason to pray is to express praise and gratitude for life itself. A deeper reason is to keep life in perspective, which is considered the most difficult lesson people must learn.

Meditation offers a way for the mind to seek clarity and the heart to find tranquility (Bell, 1998). Meditation can empty the mind of "noise" and ease tension, pain, and suffering. Becoming mindful in still and focused concentration, as in Buddhist practice, can lead to more deliberate action (Nhat Hanh, 1991). A contemplative atmosphere can be found in communion with nature or appreciation of art; quietly listening to music, whether sacred or secular, can be deeply spiritual. Shared meditative experiences foster genuine and empathic communication, reduce defensive reactivity, and deepen couple and family bonds (Bell, 1998).

\section{Rites and Rituals}

In every culture, sacred ceremonies and rituals serve invaluable functions in connecting individuals with their families and communities, as well as guiding them through life passage and times of adversity (Imber-Black \& Roberts, 1992). Rituals can celebrate family holidays, traditions, achievements, and reunions. They can ease difficult transitions or unfamiliar situations and summon courage through the darkest hours. In times of crisis and profound sorrow, they can script family actions and responses, as in funeral rites or memorial services. Rituals also connect a particular celebration or tragedy with all human experience, and a birth or a death and loss with others.

\section{Patriarchy, Sexism, and Heterosexism}

Patriarchy, a cultural pattern embedded in most religious traditions, has been a dominant force and powerful legacy. At its worst, it has sanctioned the subordination and abuse of women and children (Bottoms, Shaver, 
Goodman, \& Qin, 1995; Bridges \& Spilka, 1992). In Genesis (3:16) Eve was admonished, "In pain you shall bring forth children; yet your desire shall be for your husband, and he shall rule over you." The traditional daily prayers of Orthodox Jewish men, as well as Muslims, have included thankfulness to God (Allah) for not having been born a woman. In Islamic law, the failure of a wife to produce a male offspring is grounds for divorce (Brook, 1995). Christianity, as well, has preached a doctrine of separate and unequal sexes. St Paul told women: "You must lean and adapt yourselves to your husbands. The husband is the head of the wife." Timothy (2:11-15) pronounced, "Let a woman learn in silence with all submissiveness. I permit no woman to teach or to have authority over men; she is to keep silent." The Hindu Code of Manu (ca. 100 A.D.) declared "In childhood a woman must be subject to her father; in youth to her husband; and when her husband is dead, to her sons. A woman must never be free of subjugation." In China, Confucius (551-479 в.c.) boldly proclaimed, "One hundred women are not worth a single testicle!"(Bowman, 1983). Over the centuries, prevalent cultural norms have supported religious dogma and institutions in rigidifying more patriarchal gender roles. A legacy of this devaluation is the still-common practice of infanticide and abandonment of daughters; in many parts of Asia, abortion of a female fetus is sanctioned.

The denigration of women has alienated many from their religious roots. Some have turned to the Bahai faith (Huddleston, 1999) and to reform movements within many religions, which promote the equality of men and women in family life and society. Others have found new sources of meaning and esteem through nontraditional expressions of spirituality and interest in ancient, goddess-centered or wicca traditions. Carol Gilligan's (1982) seminal research challenged androcentric standards of moral development. Feminist scholars have sought to reinterpret and claim their rightful place in religious traditions.

Religious beliefs may underlie sexist patterns in couple and family relationships. A wife's depression or wish to leave a marriage may result from her husband's controlling and demeaning behavior, which is grounded in fundamentalist religious tenets that a wife should be submissive. One fundamentalist Christian woman reported that her husband was right to beat her because she had challenged his authority. Her husband concurred that this was her problem. As family therapists, we have an ethical responsibility to challenge beliefs that are harmful to any member, whether based in family, ethnic, or religious traditions. Above all, every religion upholds the core principles of respect for others, and the dignity and worth of all human beings.

The condemnation of homosexuality in religious doctrine has been a source of deep anguish for gay men and lesbians, who have felt exiled from most traditional faith communities (Fortunato, 1982). Some denominations preach an abhorrence for homosexual practice alongside a loving 
acceptance of homosexual persons as human beings created by God. Such a dualistic attitude nevertheless perpetuates stigma and shame, pathologizing "unnatural" sexual behavior as deviating from the proper norm (Laird \& Green, 1996; see Laird, Chapter 11, this volume). It is important to explore religious roots of rejection of gay offspring by a family of origin.

Gay men and lesbians have increasingly been forging their own spiritual pathways (O’Neill \& Ritter, 1992). Long-standing religious opposition to same-sex unions is currently being challenged by a growing number of clergy. With deep schisms over these issues in many Christian denominations in recent years, most parishioners are far more tolerant than official church doctrine.

\section{Interfaith Boundaries, Tolerance, and Marriage}

Through the mid-20th century, there were sharp divisions between different religious faiths and denominations, especially along social class and ethnic lines (Browning, Miller-McLemore, Couture, Lyon, \& Franklin, 1977; Gallup, 1996). In recent years, 25\% of adults have changed faiths or denominations from the one in which they were raised, mostly because they preferred another orientation or because of interfaith marriage.

Traditionally, many religions prohibited interfaith marriage, strongly discouraging young people from even dating someone of another denomination. Currently $32 \%$ of Catholics, $52 \%$ of Jews, and $57 \%$ of Buddhists marry outside their faith. As noted earlier, the high rate of intermarriage by Jews is of deep concern to their community (Forster \& Tabachnik, 1993). Although blacks are only half as likely as whites to oppose interracial marriages, they are more opposed than whites to interfaith marriages (Gallup, 1996). Yet, in general, acceptance has grown with the support of ecumenical and interfaith movements, and the blurring of racial and ethnic barriers. Most parents and children show increasing religious tolerance and favor public school courses to provide nondevotional instruction about various world religions. Most think that all religions are essentially good, and that people can be ethical even if they don't believe in God.

\section{Discontinuities and New Connections}

Congruence between religious/spiritual beliefs and practices yields a general sense of well-being and wholeness, whereas a dissonance can induce shame, guilt, or spiritual malaise. Discontinuities often exist between religious teachings and personal spiritual beliefs and practices. Many eschew formal institutionalized religion yet lead deeply spiritual lives. Others adhere to religious rituals without finding spiritual meaning in them. Even with the reported importance of religion, it does not necessarily change people's lives. There is often a gap between their faith and knowledge of the religion, its core tenets, and family religious roots. Many revere their 
holy scriptures but few read or study them. One survey found that although $93 \%$ of homes contain a Bible, $58 \%$ of respondents couldn't name five of the Ten Commandments; $10 \%$ thought Joan of Arc was Noah's wife (Shorto, 1997).

There is another gap between beliefs and practices. Many are strong believers but do not actively participate in congregational life. Most view their faith as a matter between themselves and God. Whereas Orthodox Jews center their lives on observance of traditional laws and practices, $62 \%$ of American Jews believe they can be "religious" without being "particularly observant" (Jewish Theological Seminary, New York, cited by Shorto, 1997).

It is important to distinguish between surface religion, such as attending church for social reasons, and deep, transforming faith that is lived out in daily life, relationships, and service to others. It is the level of spiritual commitment that makes a significant difference in personal wellbeing and concern for others. Those with a deeply integrated and livedout faith gain strength from their religious convictions and often spend significant time helping those in need. They are more likely to be tolerant of other faiths and are more giving and forgiving in their personal relationships.

Most Americans are highly independent in their spiritual lives. For instance, Catholics are among the most devout worshipers, yet $64 \%$ agree that one can be a good Catholic without going to Mass, and $82 \%$ say that using birth control is "entirely up to the individual" (Gallup, 1996). The vast majority (78\%) disagree with the Church's refusal to sanction remarriage after divorce. Sixty-two percent believe that those who have abortions are still good Catholics, and $58 \%$ believe the Church should relax its standards prohibiting abortions. Personal attitudes about abortion, euthanasia, and the death penalty are strongly polarized within and across religions. Younger people tend to be more liberal in these beliefs than their elders, often arousing intergenerational tensions within families.

Religion and spirituality are expected to grow in significance over the coming decades, shaped less by institutions and more by the people who seek meaning and connection. In our rapidly changing world, religion is less often a given that people are born into and accept unquestioningly. Instead, individuals, couples, and families commonly pick and choose among beliefs and practices to fit their lives. Canadian sociologist Reginald Bibby calls this trend "religion à la carte" (cited in Gallup, 1996, p. 8); for Deloria (1994), combining elements of varied faiths is like a platter of "religious linguini." As religious diversity within families increases, many are creating their own recipes, blending Christianity and Native American spirituality, Judaism and Zen Buddhism. Most are taking a broader ecumenical view. As McGoldrick and Giordano (1996, p. 8) observe, "We are all migrants, moving between our ancestors' traditions, the worlds we inhabit, and the world we will leave to those who come after us." 


\section{SPIRITUALITY AND CONNECTEDNESS}

Faith is inherently relational from our earliest years, when fundamental convictions about life are shaped within caretaking relationships. Intimate bonds with authentic communication ("I and Thou") are expressions of spirituality and offer pathways for spiritual growth (Buber, 1921/1970; Fishbane, 1998). Deep connections are experienced with "kindred spirits" and "soul mates." Caring relationships with partners, family members, and close friends nourish spiritual well-being; in turn spirituality deepens and expands connections with others. It can be spiritually enriching to care for an infant or a frail elder, to befriend strangers, or to receive the loving kindness of others. For many, belief in a personal relationship with God strengthens them through their darkest hours (Becvar, 1996; Griffith, 1999).

Faith, intimacy, and resilience are intertwined (Higgins, 1994). Love sustains lives and infuses them with meaning. Victor Frankl (1946/1984), in recounting his experiences in Nazi prison camps, came to the realization that salvation is found through love. As he visualized the image of his wife, a thought occurred: "I didn't even know if she were still alive. I knew only one thing-which I have learned well by now: Love goes very far beyond the physical person of the beloved. It finds its deepest meaning in his spiritual being, his inner self."

The transcendent sense of family and community is forged through shared values, commitment, and mutual support through adversity. Banning together in activism for such concerns as environmental protection or social justice can be a powerful expression of spirituality (Perry \& Rolland, 1999). In contrast to the highly individualized concept of human autonomy centered on the "self" in Western societies, most cultures in the world consider the person as embedded within the family and larger community. The African theologian John Mbiti (1970) describes this sociocentric view of human experience with the dictum, "I am because we are."

Spiritual connection and renewal can be found in nature and in great works of art, literature, and music that communicate our common humanity. Music offers a powerful transcending experience. African-American gospel "spirituals," blues, jazz, and "soul" music were creative expressions forged out of the cauldron of slavery, racism, and impoverished conditions, transcending those scarring experiences through the resilience of the human spirit.

Often, people who have had negative experiences of religion in childhood, find such ways of expressing their spirituality. The author Alice Walker found hers through communion with nature, creative writing, and activism. In a collection of essays, Walker (1997) wrote about her life as an activist and her faith in the human heart. She described her beloved mother, who was devoted to her rural church, as someone who took action, took children in need into her home, and looked out for the welfare of 
others in her struggling, isolated community. She notes that her mother would not have thought of herself as an activist but would have called it just being a person.

Walker's own spiritual journey began in a childhood subjected to "white orthodox Christianity," which her parents followed. She dropped out at age 13, feeling that the preacher and the church structure reinforced the gender inequality she saw elsewhere. She found that instead of church attendance, nature nourished her through long country walks, being out in the rain, or running with the wind. She became what she calls a "born-again pagan," experiencing spirituality through the land as a country dweller, a peasant. Her activist spirit found powerful expression in her writing and her work in movements for social justice. Her deep spirituality nourished her conviction that if you just accept conditions and do nothing, nothing changes, and you shut down; instead, activism transforms; it's impossible to stay depressed about anything if you act to change it (Walker, 1997).

\section{IMPLICATIONS FOR CLINICAL PRACTICE}

Most people who come for therapeutic help today are seeking more than symptom reduction, problem-solving, or communication skills; they are seeking deeper meaning and connections in their lives. For many, spiritual distress is at the core of physical, emotional, and relational problems. Clinicians are only beginning to develop ways to integrate this vital dimension in therapeutic work and to encourage spiritual connections in family and community life.

Moreover, psychotherapy itself, long considered a healing art, can be a profoundly spiritual experience for both clients and therapists, yet this has been a hidden aspect of clinical work (Walsh, 1999b). The very essence of the therapeutic relationship and meaningful change is ultimately spiritual in nature, fostering personal transformation, wholeness, and relational connection with others.

Throughout the mental health field, until only recently, spirituality has been purposefully left out of clinical training and practice, regarded as a taboo subject to be checked at the office door by both client and therapist. Therapists have been reluctant to raise the subject and uncomfortable in dealing with it when it does arise. When clients sense that spirituality doesn't belong in the clinical context, they censor themselves from bringing this dimension of their lives into the therapeutic conversation.

Currently, there is a growing surge of interest in spirituality by mental health professionals. Yet most feel ill-equipped in their training, constrained from broaching the subject with clients, and unsure how to approach the spiritual dimension of their therapeutic practice. Clinicians are encouraged to move beyond these barriers and find ways to incorporate 
spirituality in clinical assessment and intervention, in an effort to understand spiritual sources of distress and tap resources in healing, recovery, and resilience.

\section{Overcoming Barriers}

Several influences have contributed to the long-standing lack of attention to spirituality in clinical practice and family research (Prest \& Keller, 1993).

\section{Sacred and Secular}

One assumption has been that religion is not the proper domain of mental health professionals. Like the larger society's founding principle of separation of the religious from the secular, rigid boundaries separated spiritual concerns as "off limits" from psychotherapy. Therapists were trained not to intrude into clients' "private" spiritual matters or impose their own religious views. Spiritual distress was seen to exist in a separate realm from physical and psychosocial distress, restricted to the domain of clergy or pastoral counselors. Likewise, spiritual healing practices were deemed outside the province of mental health and health care.

\section{Power and Influence}

A related barrier involves the potential in the therapeutic relationship for vulnerable clients, in distress, to adopt their therapist's spiritual orientation. Concerns about therapists' persuasion and clients' susceptibility stem from recognition of the power of the therapist and the dependent position of clients. Therefore, professionals were trained to remain objective and unbiased. To protect clients, they were advised to be cautious not to reveal their own values or practices. However, there has been growing recognition that therapists cannot be neutral or value-free. Inescapably, therapy involves the interaction of therapists' and clients' value systems. Just as other aspects of culture (e.g., ethnicity, social class, and gender) influence client and therapist constructions of norms, problems, and solutions, so too does the spiritual dimension of experience. What we ask and pursue-or do not-influences the therapeutic relationship, course, and outcome.

We best respect clients not by avoiding discussion of spirituality altogether, but by demonstrating active interest in exploring and understanding their values and practices. In doing so, it is important to affirm and encourage those that foster well-being. At times, certain beliefs or practices may be challenged if they contribute to distress or are harmful to others, such as when violence is rationalized by citing fundamentalist religious precepts. To be both self-aware and sensitive to clients, is important for 
therapists to examine and come to understand their own orientation to religion and spirituality. It is best to recognize spiritual influences and work collaboratively in ways that foster resilience and empowerment in clients, their family relationships, and their communities (Walsh, 1998b).

\section{Science and Faith}

Historically, the psychological and the spiritual were one and the same. In fact, psyche is the Greek word for spirit. Some problems are still seen and treated as possession by spirits in many traditional cultures (Comas-Diaz, 1981; Falicov, 1999). Over the centuries, faith healers and clergy have held influential roles as counselors in their communities, tending to emotional suffering and marital/family relational problems.

Despite psychotherapy's roots in spiritual healing traditions, 20th century developments in the mental health field produced a schism: The scientific paradigm emerged as the dominant epistemology, along with skepticism toward faith-based approaches. Although many marriage and family therapists came out of pastoral counseling traditions, most mental health professionals have been trained to uphold firm boundaries between the "helping professions" and faith-based healing. Professional disciplines have sought to gain scientific credibility and status through empirically based practice, distancing from aspects of client experience and therapeutic processes that presumably could not be observed and measured.

Increasingly, possibilities for integration of science and spirituality are being pursued. Qualitative studies are gaining credence as methods to explore the meaning of experiences, yielding more knowledge about the role of faith beliefs and practices in problem construction and solution (Wright et al., 1996). Quantitative studies have begun to find empirical support for spiritual influences in mental health (Gartner, Larson, \& Allen, 1991; Hood, Spilka, Hunsberger, \& Gorsuch, 1996) and physical well-being (Koenig et al., 1998), and for the healing power of prayer (Dossey, 1993). Studies of meditation document its influence in reducing stress and blood pressure, improving sleep and mental alertness, managing chronic pain, and raising self-esteem and lowering reactivity in relationships. Over the past decade, the mental health disciplines have brought greater attention to religion and spirituality in research and practice (e.g., Shafranske, 1996; Steere, 1997; Woolfolk, 1998).

\section{Healing and Treatment}

Family therapists have approached healing in terms of a therapeutic relationship that encourages clients' own inherent healing potential. This collaborative approach is at the core of strength-based and resilience-oriented models of practice (Walsh, 1998b). Distinct from curing, healing is seen as a natural process in response to injury or trauma. Sometimes peo- 
ple heal physically but do not heal emotionally, mentally, or spiritually; badly strained relationships remain unhealed. Some may recover from an illness but not regain a spirit to live and love fully. Yet we can heal psychosocially even when we do not heal physically, or when a traumatic event cannot be reversed. The literal meaning of healing is becoming whole, and when necessary, adapting and compensating for losses of structure or function (Weil, 1994). Our faith in each family's desire to be healthy and its potential for healing and growth can encourage family members' best efforts (see Walsh, Chapter 15, this volume).

Healing and treatment are quite different concepts. Healing involves a gathering of resources within the person, the family, and the community, and is fostered through the therapeutic relationship; treatment is externally administered by experts. Western scientific medicine has focused on identifying external agents of disease and developing technological weapons to defeat them. An unbalanced focus on pathology rather than health contributes to despair (Weil, 1994). In contrast, medicine grounded in Eastern religious and philosophical traditions is based on a set of beliefs about healing processes and the importance of mind-body interactions. Healing is a functional system, not an assemblage of structures. Chinese medicine, for instance, explores ways of increasing internal resilience as resistance to disease, so that people can remain healthy regardless of the harmful influences to which they are exposed. This belief in strengthening protective processes assumes that the body has a natural ability to heal and grow stronger. A number of recently developed "alternative" approaches to medicine and psychotherapy draw on these beliefs to decrease pain and foster greater well-being (e.g., Kabat-Zinn, 1990).

Resources for diagnosis, self-repair, and regeneration exist in all of us and can be activated as need arises. Strengths-based approaches to practice encourage a family's own healing resources and reduce vulnerability. Emphasis has shifted from earlier focus on therapist techniques to see the fundamental power for change as residing within the family, and to encourage clinicians to tap into the family's own healing forces (Minuchin, 1992). In strengthening resilience, we inspire people to believe in their own possibilities for regeneration. Therapy best fosters this resilience in two ways: through a healing therapeutic relationship that is a collaborative partnership with clients, and by activating relationship networks as a healing environment for the relief of suffering and renewal of life passage. Our faith in each family's desire to be healthy and its potential for healing and growth can encourage best efforts.

The general public has indicated a need for mental health and health care professionals to attend to the spiritual dimension in their practice. Recent surveys found that $81 \%$ of respondents prefer to have their own spiritual practices and beliefs integrated into any counseling process; $75 \%$ want physicians and therapists to address spiritual issues as part of their care. Half of elderly people say they want their doctors to pray with them 
as they face death (Gallup, 1996). In general, clients are less interested in their therapists' spiritual orientation and more interested in sharing their own spiritual concerns. When therapists neglect the potential relevance of clients' spiritual beliefs and practices, and when clients hold back spiritual concerns, therapy can leave them feeling fragmented (Bergin, 1991).

Among the early pioneers in family therapy, Gregory Bateson (1979) was visionary in seeing the unity of mind and nature in all experience. Virginia Satir stood out in embracing a broad spirituality in her practice approach $(1977 / 1988)$. More recently, a number of family therapists have been breaking down barriers to explore ways to bring spirituality into therapeutic work (e.g., Anderson \& Worthen, 1997; Becvar, 1996, 1998; Griffith \& Griffith, 2001; Kramer, 1995; Prest \& Keller, 1993; Stander et al., 1994; Walsh, 1999c). Weaver, Koenig, and Larson (1997) have called for greater collaboration with clergy in family therapy training, practice, and research. Some therapists offer special approaches with very religious families (Butler \& Harper, 1994; Griffith, 1986; Nakhaima \& Dicks, 1995; Rotz, Russell, \& Wright, 1993; Stewart \& Gale, 1994). Others address issues such as violence in fundamentalist marriages (Whipple, 1987) or the painful spiritual challenges of gay men and lesbians (Markowitz, 1998; O'Neill \& Ritter, 1992). Doherty $(1995,1999)$ criticized psychotherapy's overemphasis on self-interest and called for greater sensitivity in therapy to the moral responsibilities in loving relationships and community. His message resonates with pioneer family therapist Ivan Boszormenyi-Nagy's (1987) emphasis on the ethical dimension of intergenerational relationships (Fishbane, 1999).

\section{Incorporating Spirituality in Family Assessment}

Just as family therapists have recognized the importance of inquiring about ethnicity and other aspects of culture, assessment should routinely explore the spiritual dimension of clients' lives. Therapists should note religions orientations on family genograms, (McGoldrick, Gerson, \& Shellenberger, 1998) and also explore their significance for clients. It is important to clarify, for example, whether identifying as Christian is based in deeply held convictions or a family background that has not been followed meaningfully. Is religion associated with a loving Christ or with sin and punishment? With congregational support or rigid hierarchy and doctrine? Can a broader or more personal approach to spirituality open up potential resources in everyday life?

Table 13.1 suggests some fruitful lines of inquiry in exploring the spiritual dimension of individual, couple, and family experience. Particular attention should be focused on exploring ways that religious beliefs or experiences may contribute to current distress. It is also important to consider how past, current, or potential spiritual resources can be identified and drawn on to ease distress, strengthen resilience in dealing with adversity, 
TABLE 13.1. Inquiry into the Spiritual Dimension of Clients' Individual and Family Experience to Explore Sources of Distress and Potential Therapeutic Resources

- How important is religion or a more personal spirituality in current lives? In the family of origin? What are clients' desires for future spirituality?

- To what extent do individuals, couples and families identify with a particular religion? How observant are they in practices and congregational involvement?

- How are religious differences within a couple or family handled and accepted? How do they contribute to conflict or estrangement?

- With intermarriage and/or conversion, how was the decision made? Has it been supported by families of origin? Has it been regretted?

- What are clients' concepts of the "ideal" marriage and family of their faith? Roles of wife/mother; husband/father; sons and daughters? How do they view themselves and their own family by comparison?

- How has adversity or trauma wounded the spirit?

- How have religious/spiritual beliefs or practices contributed to problems or blocked healing and growth?

- Have religious precepts (e.g., sexist or heterosexist) contributed to client suffering or abuse?

- Has a spiritual void or cutoff from religious roots exacerbated suffering or alienation?

- How might clients' past, current, or potential spiritual resources be drawn on for healing, change, and growth?

Personal and shared faith for comfort, strength, and mutual support

Spiritual practices (e.g., prayer, meditation, ritual)

Congregational affiliation and support

Spiritual guidance and counsel by clergy

or help clients accept what cannot be changed in order to foster healing, change, and growth.

In therapeutic work, it is important to learn how each family, from its own distinct sociocultural background, blends the core principles of faith with varied aspects of family members' lives. For some, traditional religious beliefs and practices can be a positive stabilizing resource in weathering crisis. For others, they have become outmoded and fail to serve as a foundation for psychosocial and spiritual well-being. Family members who feel oppressed by religious dogma may find alternate constructions and practices consonant with larger spiritual beliefs, without rejecting spirituality altogether.

Even when presenting problems do not ostensibly involve spirituality, a spiritual source of distress may emerge. One woman was referred for therapy by her mother-in-law, who was concerned about her daughter-inlaw's continued inconsolable grief, many months after the stillbirth of her second child. Exploration with the therapist revealed the daughter-in-law's profound sense of guilt. Raised in a devout Catholic family, she fell in love 
with a Jewish man; they married in a civil ceremony, because religion did not seem very important to them at that time in their lives. When their first child, a son, was born, they agreed to handle their differences by not bringing him up in either faith. With the stillbirth of the second child, the woman believed that God was punishing her for not having baptized her son. Reluctant to reveal this to her Jewish husband and his family, she had withdrawn from them and kept her concerns to herself. Individual and couple sessions were combined to involve both partners for mutual support, open communication, and decision making. Consultation with a priest and rabbi was also helpful to them.

\section{Tapping into Spiritual Resources for Healing, Recovery, and Resilience}

Suffering, and often the injustice or senselessness of it, are ultimately spiritual issues (Wright et al., 1996). Adversity and suffering have vastly different meanings in various religious traditions (Smith, 1991), and each faith in its own way calls forth resilience (Wolin, Muller, Taylor, \& Wolin, 1999), the capacity to rebound from adversity strengthened and more resourceful (Walsh, 1998b; see Chapter 15, this volume). Resilience is an active process of endurance, self-righting, and growth out of crisis or persistent life challenges. Family resilience involves key transactional processes that enable the family system to rally in times of crisis, buffering stress, reducing the risk of dysfunction, and supporting optimal adaptation for all members. Family belief systems are a powerful influence in making meaning of adversity and suffering; they can facilitate-or constrain-growthful change (Dallos, 1991; Wright et al., 1996). When relationships have been hurtful, family members can be helped to seek compassion, reconciliation, and forgiveness, which are central to the teachings of all major religions (Hargrave, 1994).

The paradox of resilience is that the worst of times can also bring out the best. A crisis can lead to transformation and growth in unforeseen directions. It can spark a reordering of life priorities for more meaningful connections. In the midst of suffering, the hardship endured can lead to spiritual growth. In turn, spiritual beliefs and practices strengthen the ability to withstand and transcend adversity. Keys to resilience, such as meaning making, hope, courage, perseverance, and connectedness are all enhanced by spirituality (Walsh, 1998b). Faith supports the belief that adversity can be overcome. Studies suggest that beyond simply being religious what matters most is being able to give meaning to a precarious situation, having faith that there is some greater purpose or force at work, and finding solace and strength in these outlooks (see Walsh, 1998b).

In their longitudinal study of resilience in poor multiethnic families in Hawaii, Werner and Smith (1992) found that religion is an important protective factor from childhood through adulthood. Religious faith and 
affiliation-including Buddhist, Catholic, Mormon, Jehovah's Witness, and others-strengthened individuals and their families through times of adversity by providing a sense of hope, mission, and salvation. Many credited highly structured religious groups for their resilience. One woman described her deep church involvement since adolescence and her abiding faith in God: "When I felt like life wasn't worth living, there was a God who loved me and would help me come through." Follow-up studies found that resilience could be forged, transforming lives throughout the life cycle. A crisis could become an epiphany, opening lives to a spiritual dimension previously untapped.

Spiritual distress, an inability to invest life with meaning, impedes coping and mastery in the face of life challenges. Religious ideas or experiences may contribute to guilt, shame, or worthlessness. From sources in family history, culture, and spirituality, we can help clients invest in traditions, rituals, or spiritual communities that link them in more positive ways. For many, new spiritual wellsprings can be tapped to offer a larger vision of humanity and connection that inspires their best.

\section{Health Benefits of Faith}

Beliefs are powerful influences in health and illness (Antonovsky, 1987). Medical studies find that faith, prayer, and spiritual rituals can strengthen health and healing by triggering emotions that influence physiological systems (Ellison \& Levin, 1998). Older persons with strong religious beliefs are more likely to be satisfied with their lives and to have lower blood pressure, reducing the risk of heart disease (Koenig et al., 1998). Among elderly persons, both depression and alcohol abuse are reduced by prayer (Ayele, 1998). Those who find strength and comfort in religious outlooks survive surgery at a far higher rate than those who lack faith (Oxman, Freeman, \& Manheimer, 1995). The solace and hopefulness of strong faith appear even more important than frequency of participation in religious services or activities. A review of medical studies on the efficacy of prayer (Dossey, 1993) similarly found that prayer triggers emotions that in turn positively impact the immune and cardiovascular systems, thereby improving health. At the same time, caution is advised not to attribute failure to recover to a lack of personal spiritual piety.

\section{Facing Death; Recovering from Loss}

Facing death and the loss of a loved one are the most painful of all family challenges. Western Christian belief systems heighten the dilemma of acceptance in their emphasis on mastery and control over destiny. The end of life is approached in terms of loss of control and the failure of treatments-or of will. In contrast, Eastern and indigenous tribal spiritual traditions approach death as a natural part of the human life cycle. Bud- 
dhism teaches that in accepting death, we discover life. Indian tribal religions approach death within the larger context: viewing human beings as an integral part of the natural world (Deloria, 1994). In death, as the soul enters the spirit world, the body is contributed and becomes the dust that nourishes the plants and animals that in turn feed people during their lifetime. Because the family and tribal community are seen as a continuing unity, death, although saddening, is simply a transitional event in a much larger human life cycle.

People of many faiths believe that the spirit lives on after the death of the body. Some believe the soul resides in a spirit world for all eternity; many believe they can be in contact or receive visits from spirits, particularly in times of need, to offer reassurance to the bereft, or when a serious wrong has not been addressed. For believers, the spirits of the deceased live on in the minds, hearts, and stories of loved ones. They can haunt as ghosts or become guardian angels and guiding spirits, inspiring best efforts and actions.

Religious beliefs can impede family response to loss (Bohannon, 1991), especially with complicated deaths, such as suicide, that may be morally condemned (Domino \& Miller, 1992). They can also facilitate family adaptation (Gilbert, 1992). The end of life offers gifts to those who face it openly with courage and compassion, reaching out to loved ones. More than any other human experience, death and loss can teach us about the meaning of life and put us in touch with what most matters in our lives; thus, the experience can be transforming. Therapists can help families face death and loss by encouraging members' full presence and participation in the dying process, drawing on their spiritual beliefs and practices to assist them.

Some devastating losses can turn people away from faith. A deeply religious couple was referred for counseling after the death of their only child. When asked if they were able to find solace in their faith, the husband shouted, "I'm angry at God!" As the therapist explored the meaning of the loss for him, he sobbed, "I believe that when something happens, there's always a reason. And I just can't fathom what the reason is here. We did everything right, by the book. God took our son. And it's not fair. He never had a chance at life." Therapists trained to help families solve problems may feel helpless and uneasy at such times; we are powerless to stop death or bring back a loved one. Often, consultation with clergy can help people find their spiritual moorings.

\section{Recovery from Substance Abuse and Addictions}

Researchers and clinicians have often overlooked the role of spiritual beliefs and practices in preventing substance abuse and relapse (Gorsuch, 1995). An emphasis on spirituality has been a key component in 12-step programs of recovery from addictions, such as Alcoholics Anonymous 
(Minnick, 1997), which can be a valuable adjunct to couple or family therapy (Berenson, 1990). In addition to offering fellowship and group support, these programs address spiritual issues concerning identity, integrity, inner life, and interdependence (Peteet, 1993). The steps are designed to promote a spiritual awakening that prepares individuals and family members to practice the principles of abstinence and greater well-being in all aspects of their lives. The connection with a Higher Power through prayer and meditation also facilitates reflection that sustains them through times of trouble. Often, this spiritual awakening sparks life-altering transformations.

\section{Overcoming Barriers of Racism and Poverty}

Religious faith and congregational support help families to survive and transcend impoverished conditions, barriers of racism, and other adversity (Billingsley, 1992; Boyd-Franklin \& Lockwood, 1999; see Boyd-Franklin, Chapter 10, this volume). In Bread and Spirit, Harry Aponte (1994) urges therapists to attend to spiritual as well as practical needs of poor families that have lost hope and faith in their chances for a better life. At the core, they suffer a poverty of despair, a wounding of the soul in a pervasive sense of injustice, helplessness, and rage at the inequalities surrounding them. Aponte encourages therapists to go beyond theory and technique to reach for meaning and purpose in people's lives:

Therapy can be an enemy or a friend to spirit. The technology of therapy has attempted to replace tradition, ritual, and customs. ... However, just as medication can only succeed when it cooperates with the healing powers of the body, therapy only works when it joins with the indigenous forces of culture and faith in people's lives. (p. 8)

In the midst of despair, a spirit of love, courage, and hope can be rekindled. Aponte (1999) believes that therapists can make a difference by recognizing that potential and joining in a revitalization of family and community spirit.

\section{Reconnecting with Family Religious Roots}

Therapists trained to look to family-of-origin history for problems and conflicts need to rebalance their focus to search for strengths. Faith is often a powerful source of resilience in weathering losses and adaptive challenges. Discovering such connections and the strength of religious roots can be a valuable part of therapeutic work, especially where experiences of oppression or forced migration have shattered a coherent sense of identity and severed linkages with ancestors. For instance, many African American descendants of Muslims brought from west Africa as slaves may be unaware of this heritage, because the practice of African religions was suppressed. 
Islam was often practiced in secret and passed down surreptitiously in oral history or by "strange" customs. Mahmoud (1996) has found that in doing genograms with African Americans in clinical practice, a story might surface of a distant relative who prayed facing east, refused to eat pork, or gave children non-Christian names. Restoring vital bonds with a family's religious heritage can be healing and empowering.

\section{Use of Meditation and Rituals}

Meditation is becoming widely used to enhance the work of therapy in various ways. Therapists' own practice of meditation outside therapy can increase therapeutic rapport, focus, and effectiveness with greater ease and success as the process flows more naturally (Rosenthal, 1990). In therapy, contemplative questions can facilitate reflection or respectfully challenge constraining or harmful beliefs. Therapists can encourage clients to practice meditation in a variety of forms, either in or between sessions, according to their spiritual beliefs, preferences, and comfort. Contrary to concerns that fragile clients might experience dissociation, meditation supports integration and wholeness: a clearer knowledge and acceptance of oneself and a deeper connection with others (Bell, 1998). Deep breathing exercises connect mind, body, and spirit (Nhat Hanh, 1991). At the same time therapists are cautioned to proceed slowly and prepare clients for whom painful memories and feelings may emerge, such as survivors of trauma, helping them to hold such experiences in a safe, bounded, and centered way (Barrett, 1999). A therapist might have a client visualize and describe a caring person and interaction from childhood, such as the secure and comforting feeling of being cradled in the arms of a grandmother.

Therapists can also ask about and encourage spiritual rituals that have been meaningful in a family's past (Imber-Black \& Roberts, 1992). They can help clients transform empty rituals into meaningful ones, create new ceremonies, or bridge formal religious differences in an expression of spirituality that is both more personal and transcendent. Including children and elders in rites of passage, especially around loss and disruptive transition, is especially important in their adaptation.

\section{Encouraging Faith-Based Activism}

The Reverend Martin Luther King, a guiding spirit to so many oppressed people throughout the world, maintained an abiding faith that social justice will prevail. Yet his was not a passive faith, waiting for a better world to happen. Rather, it was a rallying call of individual and collective action to bring about change. Studies have found that people gain resilience in overcoming adversity and heal from trauma through collaborative efforts to right a wrong or to bring about needed change in larger systems 
(Walsh, 1998b). Following her daughter's brutal murder, one mother, consumed by rage and helplessness, did not want to go on living. At her therapist's encouragement, she visited her daughter's grave to seek inspiration for the path ahead. That night, she slept deeply for the first time and awoke "knowing" that her daughter's spirit would want her to forge a larger purpose and benefit to others out of the tragedy. She turned self-destructive feelings into concerted action with other families and community leaders to reduce neighborhood violence. Perry and Rolland (1999) bring this vital dimension of faith-based activism into clinical practice.

\section{Responsiveness to Spiritual Diversity}

As societies become increasingly diverse, clinicians have more contact with different faiths and the need to develop a spiritual pluralism with knowledge and respect for varied beliefs and practices. Therapeutic approaches and services need to be sensitive and responsive to this spiritual diversity. Clinicians, especially those from dominant cultural groups, must be cautious not to take their own values as the norm, or be judgmental toward faith differences. Instead, they should seek to understand the meaning and function of faith for each family and its members.

Cultural traditions and spiritual beliefs must be understood and integrated in a holistic approach to mental health and health care (see McGoldrick, Chapter 9; Falicov, Chapter 11, this volume). When one Hmong family from southeast Asia brought a young daughter to a hospital emergency room with a seizure, a cross-cultural crisis ensued (Fadiman, 1997). The family members wanted the daughter's distress alleviated, but they did not want to stop her seizures, which they believed to be sacred trance states signifying positive connection with the spiritual world. As they put it, "The spirit catches you and you fall down." The well-intentioned medical staff obtained a court-ordered removal of the girl from her parents in order to treat her seizures. However, this only heightened her distress and alienated the family, which refused further treatment after the girl's return home, resulting in tragedy. If the health care professionals had tried to understand and work with the spiritual beliefs of the family, instead of taking an adversarial approach, the tragedy might well have been averted.

With growing religious diversity within families, therapists may need to take a role somewhat like that of a culture broker (McGoldrick \& Giordano, 1996). Where there is conflict or estrangement, therapists can help partners, parents, or extended family members to better understand and respect one another's beliefs and practices. To resolve conflicts, therapists can help members avoid polarization or shift from a stance of "moral superiority" to an acceptance of different spiritual pathways. If a therapist is of the same religion as clients, it can be easier to form a natural rapport. However, one can easily overidentify with them or be hesitant to question beliefs assumed to be fundamental. 
Clinical training can encourage therapists to explore their own family religious traditions and reflect on their own spiritual journeys (Roberts, 1999). Therapists may not be knowledgeable about the many, varied religious orientations of clients and are not trained to offer religious counseling. Yet clinical practice can be informed by the emerging literature on common beliefs and practices in families of various faith traditions (see, e.g., Almeida, 1996, on Hindu families; Butler \& Harper, 1994, on religious Christian couples; Comas-Diaz, 1981, on Puerto Rican Espiritismo; Cornwall \& Thomas, 1990, on Mormon families and communities; Daneshpour, 1998, on Muslim families). McGoldrick (see Chapter 9, this volume) stresses that culturally sensitive practice begins with awareness of the profound influence of core beliefs and an openness to learn from clients. As with other cultural matters, therapists need to openheartedly listen and explore spiritual concerns and beliefs that have profound implications for healing and growth.

\section{NOTE}

1. Nearly all reported statistics on religious beliefs and affiliations, in reference works such as Encyclopedia Brittanica and World Almanac, are obtained from a single source, Gallup Surveys, conducted by the Princeton Religion Research Center, headed by George Gallup, Jr. Quarterly newletters reporting recent polls on paticular topics can be obtained by contacting the Center at 1-609-921-8112.

Actual membership data reported by Christian church denominations throughout North America are gathered by the National Council of Churches of Christ and are presented in the Yearbook of American and Canadian Churches 1998, edited by Eileen Lindner.

\section{REFERENCES}

Almeida, R. (1996). Hindu, Christian, and Muslim families. In M. McGoldrick, J. Giordano, \& J. Pearce (Eds.), Ethnicity and family therapy (2nd ed., pp. 395-423). New York: Guilford Press.

Anderson, H. (1994). The recovery of the soul. In B. Childs \& D. Waanders (Eds.), The treasure in earthen vessels: Explorations in theological anthropology (pp. 208-223). Louisville, KY: Westminster/John Knox Press.

Anderson, H. (1999). Feet planted firmly in midair: A spirituality for family living. In F. Walsh (Ed.), Spiritual resources in family therapy (pp. 157-178). New York: Guilford Press.

Anderson, D. A., \& Worthen, D. (1997). Exploring a fourth dimension: Spirituality as a resource for the couple therapist. Journal of Marital and Family Therapy, 23, 2-12.

Antonovsky, A. (1987). Unraveling the mystery of health. San Francisco: Jossey-Bass. Aponte, H. (1994). Bread and spirit: Therapy with the new poor. New York: Norton. Aponte, H. (1999). The stresses of poverty and the comfort of spirituality. In F. 
Walsh (Ed.), Spiritual resources in family therapy (pp. 76-89). New York: Guilford Press.

Ayele, H. (1998, May). Faith and prayer linked to better quality of life. Proceedings of the American Geriatric Society Annual Meeting. Seattle, WA.

Barrett, M. J. (1999). Healing from trauma: The quest for spirituality. In F. Walsh (Ed.), Spiritual resources in family therapy (pp. 157-178). New York: Guilford Press.

Bateson, G. (1979). Mind and nature: A necessary unity. New York: Dutton.

Beavers, W. R., \& Hampson, R. B. (1990). Successful families: Assessment and intervention. New York: Norton.

Becvar, D. (1996). Soul Healing: A spiritual orientation in counseling and therapy. New York: Basic Books.

Becvar, D. (1998) (Ed.). The family, spirituality, and social work. Binghamton, NY: Haworth.

Bell, L. G. (1998). Start with meditation. In T. Nelson \& T. Trepper (Eds.), 101 interventions in family therapy (Vol. 2). New York: Haworth.

Bellah, R. N., Madsen, R., Sullivan, W., Swidler, A., \& Tipton, S. (1985). Habits of the heart. Berkeley: University of California Press.

Berenson, D. (1990). A systemic view of spirituality: God and twelve step programs as resources in family therapy. Journal of Strategic and Systemic Therapies.

Bergin, A. E. (1991). Values and religious issues in psychotherapy and mental health. American Psychologist, 46, 394-403.

Billingsley, A. (1992). Climbing Jacob's ladder: The enduring legacy of African-American families. New York: Simon \& Schuster.

Bohannon, J. R. (1991). Religiosity related to grief levels of bereaved mothers and fathers. Omega, 23, 153-159.

Boszormenyi-Nagy, I. (1987). Foundations of contextual family therapy. New York: Brunner/Mazel.

Bottoms, B. L., Shaver, P. R., Goodman, G. S., \& Qin, J. (1995). In the name of God: A profile of religion-related child abuse. Journal of Social Issues, 51, 85-111.

Bowman, M. (1983, November/December). Why we burn: Sexism exorcised. The Humanist, 28-29.

Boyd-Franklin, N., \& Lockwood, T. W. (1999). Spirituality and religion: Implications for psychotherapy with African American clients and families. In F. Walsh (Ed.), Spiritual resources in family therapy (pp. 90-103). New York: Guilford Press.

Bridges, R. A., \& Spilka, B. (1992). Religion and the mental health of women. In J. F. Schumaker (Ed.), Religion and mental health (pp. 43-53). New York: Oxford University Press.

Brook, G. (1995). Nine parts of desire: The hidden world of Islamic women. New York: Anchor Books.

Browning, D. S., Miller-McLemore, B., Couture, P., Lyon, K., \& Franklin, R. (1977). From culture wars to common ground: Religion and the American family. Louisville, KY: Westminster Press/John Knox Press.

Browning, D. S., Miller-McLemore, B., Couture, P., Lyon, K., \& Franklin, R. (2001). From culture wars to common ground: Religion and the American family (2nd ed.). Louisville, KY: Westminster Press/John Knox Press.

Buber, M. (1970). I and thou. New York: Charles Scribner's Sons. (Original published in 1921) 
Burton, L. A. (1992). Religion and the family: When God helps. New York: Haworth Press.

Butler, M. H., \& Harper, J. M. (1994). The divine triangle: God in the marital system of religious couples. Family Process, 33, 277-286.

Campbell, J., \& Moyers, B. (1988). The power of myth. New York: Doubleday.

Chamberlain, K., \& Zika, S. (1992). Religiosity, meaning in life, and psychological well-being. In J. F. Schumaker (Ed.), Religion and mental health (pp. 138-148). New York: Oxford University Press.

Coles, R. (1990). The spiritual life of children. Boston: Houghton Mifflin.

Coles, R. (1997). The moral intelligence of children. New York: Random House.

Comas-Diaz, L. (1981). Puerto Rican Espiritismo and psychotherapy. American Journal of Orthopsychiatry, 51, 636-645.

Cornwall, M., \& Thomas, D. L. (1990). Family, religion, and personal communities: Examples from Mormonism. Marriage and Family Review, 15, 229-252.

Dallos, R. (1991). Family belief systems, therapy, and change. Philadelphia: Open University Press.

Daneshpour, M. (1998). Muslim families and family therapy. Journal of Marital and Family Therapy, 24, 355-368.

D'Antonio, W. V., Newman, W. M., \& Wright, S. A. (1982). Religion and family life: How social scientists view the relationship. Journal for the Scientific Study of Religion, 21, 218-225.

Deloria, V., Jr. (1994). God is red: A native view of religion (2nd. ed.). Golden, CO: Fulcrum.

Doherty, W. J. (1995). Soul searching: Why psychotherapy must promote moral responsibility. New York: Basic Books.

Doherty, W. J. (1999). Morality and spirituality in therapy. In F. Walsh (Ed.), Spiritual resources in family therapy (pp. 179-192). New York: Guilford Press.

Domino, G., \& Miller, K. (1992). Religiosity and attitudes toward suicide. Omega, 25, 271-282.

Dossey, L. (1993). Healing words: The power of prayer and the practice of medicine. San Francisco: Harper.

Elkind, D. (1971). The development of religious understanding in children and adolescents. In M. P. Strommen (Ed.), Research of religious development (pp. 655-685), New York: Hawthorn Books.

Ellison, C. G., \& Levin, J. S. (1998). The religion-health connection: Evidence, theory, and future directions. Health Education and Behavior, 25, 700-720.

Erikson, E. H., Erikson, J. M., \& Kivnick, H. Q. (1986). Vital involvement in old age. New York: Norton.

Fadiman, A. (1997). The spirit catches you and you fall down. San Francisco: Ferrer.

Falicov, C. (1995). Cross-cultural marriages. In N. Jacobson \& A. Gurman (Eds.), Clinical handbook of couple therapy (Vol. 3, pp. 231-246). New York: Guilford Press.

Falicov, C. (1999). Religion and spiritual folk traditions in immigrant families: Therapeutic resources with Latinos. In F. Walsh (Ed.), Spiritual resources in family therapy (pp. 104-120). New York: Guilford Press.

Fishbane, M. (1998). I, thou, and we: A dialogical approach to couple's therapy. Journal of Marital and Family Therapy, 24, 41-58.

Fishbane, M. D. (1999). Honor thy father and thy mother. In F. Walsh (Ed.), Spiritual resources in family therapy (pp. 136-156). New York: Guilford Press.

Forster, B., \& Tabachnik, J. (1993). Jews-by-choice: Conversion factors and out- 
comes. In M. Lynn \& D. Moberg (Eds.), Research in the social scientific study of religion (Vol. 5, pp. 123-155). Greenwich, CT: JAI Press.

Fortunato, J. (1982). Embracing the exile: Healing journeys of gay Christians. San Francisco: HarperCollins.

Frankl, V. (1984). Man's search for meaning. New York: Simon \& Schuster. (Original published in 1946)

Friedman, E. H. (1985). Generation to generation: Family process in church and synagogue. New York: Guilford Press.

Galanter, M. (1989). Cults and new religious movements. Washington, DC: American Psychological Association.

Gallup, Jr., G. (Ed.). (1996). Religion in America: 1996 report. Princeton, NJ: Princeton Religion Research Center.

Gallup, G., Jr., \& Lindsey, D. M. (1999). Surveying the religious landscape: Trends in U. S. beliefs. Harrisburg, PA: Morehouse.

Gartner, J., Larson, D. B., \& Allen, G. D. (1991). Religious commitment and mental health: A review of the empirical literature. Journal of Psychology and Theology, 19, 6-25.

Gaustad, E. S. (1966). A religious history of America (rev. ed.). San Francisco: Harper \& Row.

Gilbert, K. (1992). Religion as a resource for bereaved parents. Journal of Religion and Health, 31, 19-30.

Gilligan, C. (1982). In a different voice: Psychological theory and women's development. Cambridge, MA: Harvard University Press.

God in America [Special issue]. (1998). Life, 21(13).

Gorsuch, R. L. (1995). Religious aspects of substance abuse and recovery. Journal of Social Issues, 51, 65-83.

Greeley, A. (1969). Why can't they be all like us? New York: American Jewish Committee.

Griffith, J. L. (1986). Employing the God-family relationship with religious families. Family Process, 25, 609-618.

Griffith, J. L., \& Griffith, M. E. (2001). Encountering the sacred in psychotherapy: How to talk with people about their spiritual lives. New York: Guilford Press.

Griffith, M. E. (1999). Opening therapy to conversations with a personal God. In F. Walsh (Ed.), Spiritual resources in family therapy (pp. 209-222). New York: Guilford Press.

Hargrave, T. (1994). Families and forgiveness. New York: Brunner/Mazel.

Higgins, G. O. (1994). Resilient adults: Overcoming a cruel past. San Francisco: JosseyBass.

Hochschild, A. (1997). Time bind. New York: Holt.

Hood, R. W., Spilka, B., Hunsberger, B., \& Gorsuch, R. (1996). The psychology of religion: An empirical approach (2nd. ed.). New York: Guilford Press.

Huddleston, J. (1999). The earth is but one country (4th ed.) New Delhi: Baha'i Publishing Trust.

Imber-Black, E., \& Roberts, J. (1992). Rituals for our times: Celebrating, healing, and changing our lives and our relationships. New York: HarperCollins.

Kabat-Zinn, J. (1990). Full catastrophe living: Using the wisdom of your mind and body to face stress, pain, and illness. New York: Dell.

Kramer, S. Z. (1995). Transforming the inner and outer family: Humanistic and spiritual approaches to mind-body systems therapy. New York: Haworth. 
Koenig, H., George, L., Hays, J. Larson, D., Cohen, H., \& Blazer, D. (1998). The relationship between religious activities and blood pressure in older adults. International Journal of Psychiatry, 28, 189-213.

Laird, J., \& Green, R. J. (Eds.). (1996). Lesbians and gays in families and family therapy. San Francisco: Jossey-Bass.

Lerner, M. (1994). Jewish renewal: A path to healing and transformation. New York: Putnam.

Lifton, R. J. (1993). The protean self: Human resilience in an age of fragmentation. New York: Basic Books.

Lindner, E. W. (1998). Yearbook of American and Canadian churches 1998 (66th ed.). Nashville: Abingdon Press.

Mahmoud, V. (1996). African American Muslim families. In M. McGoldrick, J. Giordano, \& J. Pearce (Eds.), Ethnicity and family therapy (pp. 112-128). New York: Guilford Press.

Markowitz, L. (1998). Essential conversations: Raising the sacred in therapy. In the family, 3(3), 7-13.

Mbiti, J. S. (1970). African religions and philosophy. Garden City, NY: Anchor Books.

McCourt, F. (1998, December). God in America: When you think of God, what do you see? Life, 21(13), 60-74.

McGoldrick, M., Gerson, R., \& Shellenberger, S. (1998). Genograms: Assessment and intervention (2nd. ed.). New York: Norton.

McGoldrick, M. \& Giordano, J. (1996). Overview. In M. McGoldrick, J. Giordano, \& J. K. Pearce (Eds.), Ethnicity and family therapy (pp. 1-28). New York: Guilford Press.

Minnick, A. M. (1997). Twelve step programs: Contemporary American quest for meaning and spiritual renewal. New York: Praeger.

Minuchin, S. (1992). Family healing: Strategies for hope and understanding. New York: MacMillan.

Moore, T. (1992). Care of the soul: A guide for cultivating depth and sacredness in everyday life. New York: HarperCollins.

Nakhaima, J. M., \& Dicks, B. H. (1995). Social work practice with religious families. Families in Society: Journal of Contemporary Human Services, 76, 360-368.

Nhat Hahn, T. (1991). Peace is every step: The path of mindfulness in everyday life. New York: Bantam Books.

O'Neil, C., \& Ritter, K. (1992). Coming out within: Stages of spiritual awakening for lesbians and gay men. New York: HarperCollins.

Oxman, T. E., Freeman, D. H., \& Manheimer, E. D. (1995). Lack of social participation or religious strength and comfort as risk factors for death after cardiac surgery in the elderly. Psychosomatic Medicine, 57, 5-15.

Perry, A. D. V., \& Rolland, J. S. (1999). Spirituality expressed in community action and social justice: A therapeutic means to liberation and hope. In F. Walsh (Ed.), Spiritual resources in family therapy (pp. 272-292). New York: Guilford Press.

Peteet, J. R. (1993). A closer look at a spiritual approach in addictions treatment. Journal of Substance Abuse Treatment, 10, 263-267.

Pipher, M. (1997). The shelter of each other: Rebuilding our families. New York: Ballantine.

Prest, L. A., \& Keller, J. F. (1993). Spirituality and family therapy: Spiritual beliefs, myths, and metaphors. Journal of Marital and Family Therapy, 19, 137-148. 
Roberts, J. (1999). Heart and soul: Spirituality, religion, and rituals in family therapy training. In F. Walsh (Ed.), Spiritual resources in family therapy (pp. 256-271). New York: Guilford Press.

Rosen, E. J., \& Weltman, S. F. (1996). Jewish families: An overview. In M. McGoldrick, J. Giordano, \& J. Pearce (Eds.), Ethnicity and family therapy (pp. 611-630). New York: Guilford Press.

Rosenthal, J. (1990). The meditative therapist. Family Therapy Networker, 14, 38-41, $70-71$.

Rotz, E., Russell, C. S., \& Wright, D. W. (1993). The therapist who is perceived as "spiritually" correct: Strategies for avoiding collusion with the "spiritually oneup" spouse. Journal of Marital and Family Therapy, 19, 369-375.

Satir, V. (1988). Peoplemaking. Palo Alto, CA: Science and Behavior Books. (Original published in 1977)

Shafranske, E. P. (Ed.). (1996). Religion in the clinical practice of psychology. Washington, DC: American Psychological Association Press.

Shorto, (December 7, 1997). The New York Times Magazine, p. 61.

Smith, H. (1991). The world's religions: Our great wisdom traditions (rev. ed.) New York: HarperCollins.

Some, M. P. (1994). The healing wisdom of Africa. New York: Tarcher/Putnam.

Stacey, J. (1996). In the name of the family: Rethinking family values in the postmodern age. Boston: Beacon Press.

Stander, V., Piercy, F. P., MacKinnon, D., \& Helmeke, K. (1994). Spirituality, religion, and family therapy: Competing or complementary worlds? American Journal of Family Therapy, 22, 27-41.

Steere, D. A. (1997). Spiritual practice in psychotherapy: A guide for caregivers. New York: Brunner/Mazel.

Stewart, S. P., \& Gale, J. E. (1994). On hallowed ground: Marital therapy with couples on the religious right. Journal of Systemic Therapies, 13, 16-25.

Stinnett, N., \& DeFrain, J. (1985). Secrets of strong families. Boston: Little, Brown.

Walker, A. (1997). Anything we love can be saved: A writer's activism. New York: Random House.

Walsh, F. (1998a). Beliefs, spirituality, and transcendence: Keys to family resilience. In M. McGoldrick (Ed.), Re-visioning family therapy (pp. 62-77). New York: Guilford Press.

Walsh, F. (1998b). Strengthening family resilience. New York: Guilford Press.

Walsh, F. (1998c). Families in later life: Challenges and opportunities. In B. Carter \& M. McGoldrick (Eds.), The expanded family life cycle (3rd. ed., pp. 307-326). Needham Heights, MA: Allyn \& Bacon.

Walsh, F. (1999a). Religion and spirituality: Wellsprings for healing and resilience. In F. Walsh (Ed.), Spiritual resources in family therapy (pp. 3-27). New York: Guilford Press.

Walsh, F. (1999b). Opening family therapy to spirituality. In F. Walsh (Ed.), Spiritual resources in family therapy (pp. 28-58). New York: Guilford Press.

Walsh, F. (Ed.). (1999c). Spiritual resources in family therapy. New York: Guilford Press.

Walsh, F., \& McGoldrick, M. (1991). Living beyond loss: Death in the family. New York: Norton.

Weaver, A. J., Koenig, H. G., \& Larsen, D. B. (1997). Marriage and family therapists and the clergy: A need for clinical collaboration, training, and research. Journal of Marital and Family Therapy, 23, 13-25. 
Weil, A. (1994). Spontaneous healing. New York: Knopf.

Werner, E. E., \& Smith, R. S. (1992). Overcoming the odds: High risk children from birth to adulthood. Ithaca, NY: Cornell University Press.

Whipple, V. (1987). Counseling battered women from fundamentalist churches. Journal of Marital and Family Therapy, 13, 251-258.

Wolin, S. J., Muller, W., Taylor, F., \& Wolin, S. (1999). Three spiritual perspectives on resilience: Buddhism, Christianity, and Judaism. In F. Walsh (Ed.), Spiritual resources in family therapy (pp. 121-135). New York: Guilford Press.

Woolfolk, R. (1998). The cure of souls: Science, values, and psychotherapy. San Francisco: Jossey-Bass.

Worthington, E. L., Jr. (1989). Religious faith across the lifespan: Implications for counseling and research. Counseling Psychologist, 17, 555-612.

Wright, L., Watson, W. L., \& Bell, J. M. (1996). Beliefs: The heart of healing in families and illness. New York: Basic Books. 